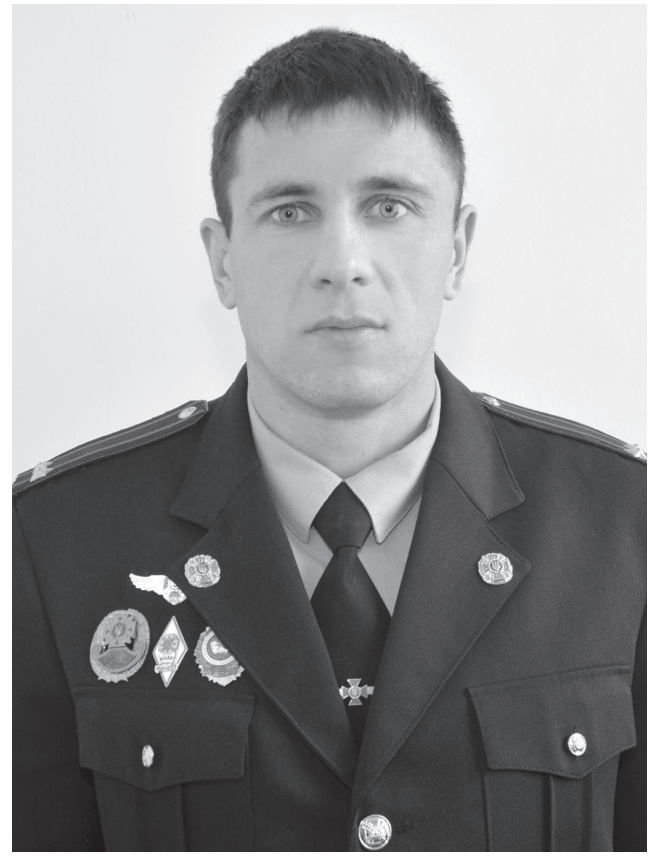

UDC 378.014(477)

Vavrenyuk Sergey Anatolievich, PhD in Public Administration, lecturer of the Department of pyrotechnic and special training, National University of Civil Defense of Ukraine, 61023, Kharkiv, Str. Chernysherska, 94, tel.: (057) 7003171, e-mail:nисzи@тns. goz.ua

ORCID: 0000-0002-6396-9906

Вавренюк Сераій Анатолійович, кандидат наук з державного управління, викладач кафедри піротехнічної та спеціальної підготовки, Національний універ ситет цивільного захисту України, 61023, м. Харків, вул. Чернишевська, 94, тел.: (057) 7003171, -mail: nuczu@mns.gov.ua

ORCID: 0000-0002-6396-9906

Вавренюк Сергей Анатольевич, кандидат наук по государственному управлению, преподаватель кафедры пиротехнической и спещиальной подготовки, Наииональньй университет гражданской защиты Украины, 61023, г. Харьков, ул. Чернышевская, 94, тел.: (057) 70031 71, е-таіl: писzи@тпs.gov.иа

\title{
INTERNAL RISKS OF THE CONTEMPORARY STATE OF HIGHER EDUCATION IN UKRAINE
}

Abstract. This article is devoted to the problem of managing internal risks affecting Ukrainian educational institutions. The author analyzes the existing internal challenges and risks in the system of higher education in Ukraine. In addition to this, the essence of the cluster approach, which is one of the effective means of overcoming the problems of the economic mechanism of public administration in the system of reform and development of higher education, is being revealed.

The author suggests that people risk is one of the most difficult and important problems of internal risks. It is noted that the solution of this problem will lead to an increase in the competitiveness of higher educational institutions and the effectiveness of the entire educational process.

It is proved that the management of internal risks is an important issue that is to be decided not only by the educational institution, but also by the entire education system of the country. The author shows the importance of improving educational services by achieving an ideal state of the internal environment of the educational institution. 
It is shown that the management of internal risks of a higher educational institution should be based on generally accepted approaches, take into account the specifics of the education sphere and a specific classification of risks and threats.

Also, the author examines the features of the cluster approach in education. It is determined that the cluster approach ensures the concentration of management efforts of educational institutions to solve educational problems, thereby contributing to the reduction of emerging internal risks in a higher educational institution. It is substantiated that the introduction of the cluster approach in the activity of the educational institution will improve the quality and social status of vocational education and increase the demand for graduates in the labor market.

In conclusion, the author says that the modern development of the education system presupposes taking into account the provisions of risk management that will be for overcoming existing internal problems and challenges, thereby ensuring the creative development of domestic universities and increasing the competitiveness of domestic education in the world market.

Keywords: internal risks, financial risks, innovative risks, people risks, public administration, cluster approach.

\section{ВНУТРІШНІ РИЗИКИ СУЧАСНОГО СТАНУ ВИЩОЇ ОСВІТИ В УКРАЇНI}

Анотація. Розглянуто проблему управління внутрішніми ризиками, які впливають на українські навчальні заклади. Проаналізовано існуючі внутрішні виклики та ризики в системі вищої освіти України. Окрім цього розкривається сутність кластерного підходу, який на сьогодні є одним з ефективних засобів подолання проблем економічного механізму державного управління в системі реформування та розвитку вищої освіти.

Визначено, що однією з найбільш складних й важливих проблем внутрішніх ризиків виступає кадровий ризик. Вирішення даної проблеми приведе до посилення конкурентоспроможності вищих освітніх закладів та ефективності усього освітнього процесу в цілому.

Доведено, що управління внутрішніми ризиками є важливим питаням, яке має вирішуватися не тільки з навчальним закладом, а й усією системою освіти країни. Підкреслено важливість підвищення освітніх послуг за допомогою досягнення оптимального стану внутрішнього середовища освітньої установи. Управління внутрішніми ризиками вищого навчального закладу має базуватися на загальноприйнятих підходах, враховувати специфіку сфери освіти та конкретну класифікацію ризиків й викликів.

Досліджено особливості кластерного підходу в освіті. Визначено, що кластерний підхід забезпечує концентрацію управлінських зусиль освітніх установ на рішення виховних завдань, тим самим сприяючи зниженню внутрішніх ризиків у вищому навчальному закладі. Обгрунтовано, що впровадження 
кластерного підходу в діяльність освітнього закладу буде підвищувати якість та соціальний статус професійної освіти, а також підвищувати потребу випускників на ринку праці.

Сучасний розвиток системи освіти передбачає врахування положень ризик-менеджменту, спрямованого на подолання наявних внутрішніх проблем та викликів, тим самим забезпечуючи інноваційний розвиток вітчизняних університетів й підвищуючи конкурентоспроможність вітчизняної освіти на світовому ринку.

Ключові слова: внутрішні ризики, фінансові ризики, інноваційні ризики, кадрові ризики, державне управління, кластерний підхід.

\section{ВНУТРЕННИЕ РИСКИ СОВРЕМЕННОГО СОСТОЯНИЯ ВЫСШЕГО ОБРАЗОВАНИЯ В УКРАИНЕ}

Аннотация. Рассмотрена проблема управления внутренними рисками, влияющими на украинские учебные заведения. Проанализированы существующие внутренние вызовы и риски в системе высшего образования Украины. Помимо этого раскрывается сущность кластерного подхода, который на сегодня является одним из эффективных средств преодоления проблем экономического механизма государственного управления в системе реформирования и развития высшего образования.

Определено, что одной из самых сложных и важных проблем внутренних рисков выступает кадровый риск. Решение данной проблемы приведет к усилению конкурентоспособности высших образовательных учреждений и эффективности всего образовательного процесса в целом.

Доказано, что управление внутренними рисками является важным вопросов, который должен решаться не только учебным заведением, но и всей системой образования страны. Подчеркнута важность повышения образовательных услуг посредством достижения оптимального состояния внутренней среды образовательного учреждения. Управление внутренними рисками высшего образовательного учреждения должно базироваться на общепринятых подходах, учитывать специфику сферы образования и конкретную классификацию рисков и угроз.

Исследованы особенности кластерного подхода в образовании. Определено, что кластерный подход обеспечивает концентрацию управленческих усилий образовательных учреждений на решение воспитательных задач, тем самым способствуя снижению возникающих внутренних рисков в высшем учебном заведении. Обосновано, что внедрение кластерного подхода в деятельность образовательного учреждения будет повышать качество и социальный статус профессионального образования и увеличивать востребованность выпускников на рынке труда.

Современное развитие системы образования предполагает учет положений риск-менеджмента, который будет направлен на преодоление имеющихся внутренних проблем и вызовов, тем самым обеспечивая инновационное 
развитие отечественных университетов и повышая конкурентоспособность отечественного образования на мировом рынке.

Ключевые слова: внутренние риски, финансовые риски, инновационные риски, кадровые риски, государственное управление, кластерный подход.

Problem statement. Risk management issues occupy an important place in the management of the economic activities of various organizations. Despite the specific market of higher education institutions services, these problems are not overlooked by the party and higher educational establishments.

The main task of risk management in this area is to ideal make sure the relationship between the desired level of risk and the necessary cash costs. In this regard, the risk management system of higher education institutions should give the necessary mechanism to overcome the problems that they are called upon.

Among the components of this system is the decision-making procedure in the case of risk, as well as the choice of methods for its prevention, the identification of responsible persons, the information management system and the system of internal control. Managing the internal risks of higher education institutions is one of the important issues that are solved by the management of the institution. Due to the high growth of competition in the market of educational services, it is important that the state of the internal environment of the educational institution is as optimal as possible. To do this, it is necessary to carry out continuous monitoring of all internal mechanisms of institutions of higher education, as well as, in assessing the situation, to timely recognize the impact of internal risks on the efficiency of management of higher education.

Analysis of recent publications on research issues. The study of risks is devoted to the work of many theorist classics, namely A. Hanna, J. Keynes, A. Smith, I. Fisher.

As for the study of the problems associated with the internal risks of the higher education system, many domestic scientists were involved. Among them, T. Bogolib, A. Tarkutsiak, V. Gelman, and others.

However, despite the wide range of studies that have been carried out in this area, today we see a lack of coverage of the issues of assessing the degree of impact of internal risks on the management of the institution of higher education.

Purpose of the article. The purpose of the paper is to study the internal risks faced by institutions of higher education from the point of view of their management and overcoming the existing problems.

\section{Presenting the main material of re-} search. Among the main internal risks that depend on internal resource and management factors, we can highlight the lack of such resources, especially students, highly skilled people, finance, computer equipment, infrastructure, etc. This is all due to the fact that to- 
day we see an inefficient process of managing the use of these resources under fairly complex external conditions [1].

The normative regulations of the Cabinet of Ministers of Ukraine offer those criteria that serve as a basis for assessing the risk of a separate educational institution for the system of general secondary, vocational and higher education. Among the criteria for assessing the level of risk in the field of higher education, it is possible to show the terms of conduct of economic activity, which provides educational services in the higher education system, and the violations of the requirements of legislation for conducting economic activity, which provides educational services in the higher education system. Such violations are the lack of legal basis for conducting educational activities in certain areas and specialties, those or other violations of the requirements for the formation of the structure of the institution of higher education and student contingent, or staffing of the educational process, or failure to make the curriculum and program. Equally important criteria for assessing the level of risk will be the results of the accreditation of educational programs; the planned performance indicators contained in the annual plans of the entity, such as, government order and financial stability.

Such criteria are usually analyzed when examining institutions of higher education, and on this basis, close on the degree of its risk, which may be insignificant, medium or high. From a scientific point of view, government procurement and financial sustainability are very important among these issues, but more complex assessment and broadening of the range of criteria, including the ratio of real contingent and licensed volumes, the unemployment rate of graduates in the region and in general, should also be taken into account. It is also important to assess the degree of risk at various levels, including the institution itself, the region, sub-sector or industry in general [2].

For the purpose of a detailed analysis of the risk management mechanisms of higher education institutions, it is necessary to consider elementary internal risks.

Among them one of the most important is the risk of lack of funds. Cash, which is in circulation, is the source of this risk. The cash received from students for education services is unevenly received in higher education institutions, since the payment is one payment at the beginning of receiving the service or twice a year, however, the costs for the functioning of educational institutions are carried out. In the event of improper management financial policy, there is a shortage of cash back in the period when there is no payment for tuition.

One more condition for the emergence of this risk may be the lack of funds in circulation, which leads to negative consequences, including the need for a loan or loan, to show a balance of cash in circulation. Therefore, for the rational management of cash in circulation, it is necessary to optimize them, which is based on the needs of the institution. An important task of managing cash in circulation will be the provision of their sources of funding. This tells us that in the foreground will be the methodological and practical issues of managing the analysis processes, 
as well as the need to discuss the problem of the formation and rational use of working capital.

Ensuring a uniform distribution of the institution's costs depend on the correct financial and economic policy of the educational institution, taking into account the uneven cash flow. Therefore, there is a need to create an appropriate reserve for certain obligatory needs and expenditures of the educational institution, while relying on indicators and forecasts of the overall economic situation in the country, calculating the amount of tuition fees. The correct determination of the amount of payment for the entire period of study, as well as its distribution by exchange in equal parts or evenly, increasing each year, is one of the important directions of the financial and economic policy of the educational institution. There is also a need to take into account the option when the student makes an early payment of the entire period of study. In this case, it is important to properly direct the flow of managed funds. Among possible options, we can divide deposits, investments in long-term projects or issuing certificates for training. All this suggests that the effective allocation and make of investment funds to meet the needs of the institution throughout the student's training will bring the most profit [3].

Among the internal financial risks is allocated investment, which for institutions of higher education, primarily associated with innovation activities. Innovative activity of institutions of higher education is the organization of educational, scientific and innovation process in four directions, namely, educational, research, administrative, management, scientific and technical. In order to manage investment risks it is necessary to carry out their timely detection, to rate and analyze the identified risks, to find the causes of their occurrence, to develop measures that will cut their impact, economically substantiate and implement the developed measures. Implementation of such stages will make it possible to increase the efficiency of management of investment risks.

Among the specific internal risks, we consider it necessary to refer to the loss of contingent, which is usually classified as working. Naturally, students are the main and only consumer of higher education institutions. Applicants form a potential contingent in a higher education institution. Recently, there is such a tendency, which is lack of entrants, which can be explained by the demographic situation in the country, the policy of the state, financial insolvency of the population. All these factors influence the significant reduction of the number of applicants, which, in turn, forces higher education institutions to intensify the competitive struggle for them. The consequences of such a risk affect all types of activities of the institution of higher education, first, on its financial status [4].

Today, we can see that analysts of the Ministry of Education and Science of Ukraine offer us a cluster approach, which allows determining the regional groups of institutions of higher education of the degree of aggravation of their internal problems.

Important features of the cluster participants are the presence of the so-called "critical mass", as well as the sufficiently high level of connections 
between the participants, that is, internal and external connectivity and novelty in the activity of the cluster participants. If we look at the last part, note that the cluster is directed and concentrated on creative enterprises (firms and institutions). It is innovative development that directs the active orientation of these structures and defines innovative activity, and is achieved by continuous improvement of the advantages as a result of various types of innovations. These include organizational, technological, technical and marketing innovations.

Summarizing the above, let us note that solving the problem of industrial cooperation precisely in the field of training of classified labor is possible due to cauterization of the sphere of education. In this case, this approach will help increase competitiveness at the regional and national levels, increase the growth of innovation potential, develop small and medium-sized businesses in the field of education and training of skilled workers, as well as in other areas.

The accumulated experience tells us that the cluster approach is not only a means of achieving the goal, combined with increasing competitiveness, as well as innovation enhancement, is also an effective means, which is an incentive for regional development that will yield a multiplier effect that will lead to an increase in employment, raise wages, as well as deductions to the budget and increase stability in competition between regions and the state as a whole [5].

Looking at the centers where clusters can be formed may be educational institutions, such as higher education institutions and each group of research and development organizations. In this case, clusters will be considered as the most effective production system in the conditions of globalization and development of modern science, that is, the knowledge economy [6].

Considering the sphere of regional development, it should be noted that it is worth developing cluster concepts. In this case, radical reforms are needed at the national level, which will lead to greater organizational and economic cooperation. However, here the main aspect of supporting the clustering process is the implementation of a policy at the national level for maintaining and developing scientific and technological progress, developing innovation, conducting administrative, financial and economic, as well as regulatory reforms and strategic development of the regions [7].

According to T. Yu. Krasnikova educational clusters are a system of joint institutions of specialized education, joined by industry and have partnerships with enterprises in the industry [8].

Considering the assertions of N. V. Vasiliev, it should be noted that the educational cluster at the regional level should be considered as a whole system of educational institutions of 1-4 level accreditation, commercial companies, organizations involved in introducing innovations into infrastructure at the regional level and levels of entrepreneurship, in close connection with the authorities and the part economic system. In line with this, she says that the center or nucleus of the cluster may be a higher education institution, which will assume responsi- 
bility for the educational and scientific support of the cluster, as well as at the same time represent an information and methodological center and communications platform [9].

O. N. Korchagina asserts that to receive an educational service, which is the product of an activity, the educational cluster should be a group of educational institutions in the same region and in partnership. In this approach, the center of the educational cluster will be a higher education institution or another educational organization [10].

Educational cluster in the sense of O. V. Smirnov is an innovation chain "science-technology-business", which is connected horizontally within each other and is a system of training, mutual learning, and self-learning tools. In this approach, the educational cluster is the basis of the educational process, which enables one to view this cluster on both sides: as a system and as a process [11].

But the educational cluster should be seen as a more voluminous, with regard to the market of educational services, the concept. That is, the system of interconnected higher education institutions and educational organizations, the significance of which is quite large. Such a concept can be defined with such forms of integration between industries as joint ventures, holding structures, strategic alliances, network associations, industrial parks, industrial parks, economic zones.

In our opinion, the educational cluster is a more complex process than the usual association of educational institutions, organizations and enterprises, because these institutions take part in the process of co-operation and compete with each other.

The process of continuous education from the preschool institution, from school to production itself, is one system that eventually forms an educational cluster.

In addition note that the educational innovative socio-cultural cluster is a close interacting economic entity that is voluntarily united geographically and includes: educational institutions, authorities, the banking and private sector, innovation organizations, various objects infrastructures that include the production of competitive educational, social and cultural services, a directed development strategy, the realization of the interests of all participants, as well as the site of the cluster where it is located and has an important socio-economic role in the region. The purpose of the cluster is to unite the efforts, capabilities, and potential of the subjects of the new structure for the implementation of mutually agreed actions for improving the quality of education in the regions, its competitiveness both at the domestic and world levels.

Summing up the above, we can say that under the notion of an educational cluster one should mean an alliance connected with each other and the territory, institutions of higher education, which leads to the development and growth of competitiveness of each of them, and their activities are aimed at achieving innovative technologies and quality training of workers for the regional and national labor market.

Conclusions. Thus, in the economic mechanism of public administration in the system of reforming and developing higher education in Ukraine, we can 
see the need for changes in the national higher education system in terms of its readiness for contemporary development, among which new approaches to the allocation of not only educational but also educational and scientific clusters.

Along with this, we can talk about the inadequacy of the response to the challenges and risks of the external and internal environment at the institutional, regional and national levels.

This is all the more so as today we are seeing big global, political and economic challenges in the field of higher education, which are conditioned by the global trend and the specific conditions of our time, which allows us to close on the need for a timely and well-founded analysis of such challenges and risks as the basis for development of thought-out and effective decisions for their implementation in the state educational policy. We can say that domestic higher education has a significant margin of safety, which is important not only to keep, but also to multiply. The current stage of development involves the formation of professional risk management in the higher education system, as modern creative development of Ukrainian universities and the entire educational system can only be ensured if we expect events than act in a reaction to those or other risks.

\section{REFERENCES}

1. Zayarnaya I. A. (2014). Vliyanie vnutrennih riskov na upravlenie vuzami [Influence of internal risks on the management of universities]. Fundamental research. № 6-4. p. 785-788.
2. Vavrenyuk S. (2018). Gosudarstvennoe regulirovanie reformirovaniya vysshego obrazovaniya Ukrainy na sovremennom etape [State regulation of the reform of higher education in Ukraine at the present stage]. Est journal of security studies: Sciences. Journal. Vip. 2 (12). p. 15-24.

3. Selezneva N. A. (2003). Kachestvo vysshego obrazovaniya: opyt sistemnogo issledovaniya [The quality of higher education: the experience of system research]. Mater. Int. scientific-theor. Conf. National system for assessing the quality of education: problems, strategy, technology. Taraz: Taraz University, p. $32-54$.

4. Grechenko D. A., Chulyukov V. A. (2010). Strukturnaya komponenta modeli organizacionnogo upravleniya vysshim uchebnym zavedeniem [Structural component of the model of organizational management of higher education institutions]. Modern high technology. № 4. p. 13-16.

5. Krasilnikov I. O. et all. (2014). Innovacii v upravlenii vuzom: novye resheniya dlya korporativnoj informacionnoj sistemy [Innovations in university management: new solutions for the corporate information system]. University management. № 6 (46). p. 16-24.

6. Kaleniuk I. S. (2015). Suchasni riziki rozvitku vishoyi osviti $\mathrm{v}$ Ukrayini [Modern Risks of the Development of Higher Education in Ukraine], Economics of Ukraine. 2. p. 70-83.

7. Dombrozska S. N. (2011). Mehanizmi realizaciyi derzhavnoyi politiki v galuzi vishoyi osviti [Mechanisms for the implementation of state policy in the field of higher education]. Actual problems of public administration. № 2. p. 107113.

8. Krasikova T. Yu. (2011). Obrazovatelnyj klaster kak faktor vzaimodejstviya rynka truda i sistemy vysshego professionalnogo obrazovaniya [Educational 
cluster as a factor in the interaction of the labor market and the system of higher professional education]. Actual problems of economics and management: materials of the international. sci. Conf., April 2011: theses additional. Vol. II. p. 54-59.

9. Vasilyeva N. V. (2013). Formirovanie i razvitie obrazovatelnyh klasterov $\mathrm{v}$ regionalnoj socialno-ekonomicheskoj sisteme: avtoref. na soiskanie uchenoj stepeni kand. ekon. nauk: specialnost 08.00.05 "Ekonomika i upravlenie narodnym hazyajstvom (regionalnaya ekonomika)" [Formation and development of educational clusters in the regional socio-economic system: the author's abstract for the academic degree of Cand. econ. Sciences: specialty 08.00.05 "Economics and management of the national economy (regional economy)"]. Gatchina. Poland.

10. Korchagina N. A. (2009). Obrazovatelnye klastery kak osnova povysheniya konkurentosposobnosti uchebnyh zavedenij [Educational clusters as a basis for increasing the competitiveness of educational institutions]. Prikaspiysky Journal: Management and High Technologies. № 3 (7). p. 78-84.

11. Smirnov A. V. (2010). Obrazovatelnye klastery i innovacionnoe obuchenie $\mathrm{v}$ vuze: monografiya [Educational Clusters and Innovative Education in the University: Monograph]. Kazan.

\section{СПИСОК ВИКОРИСТАНИХ ДЖЕРЕЛ}

1. Заярная И. А. Влияние внутренних рисков на управление вузами // Фундаментальные исследования. 2014. - № 6-4. - С. 785-788.

2. Вавренюк C. А. Государственное регулирование реформирования высшего образования Украины на современном этапе / С. А. Вавренюк //
East journal of security studies: наук. журнал. - Х.: Вид-во НУЦЗУ; Гданськ (Польща), 2018. - Вип. 2 (12). C. 15-24.

3. Селезнева Н. А. Качество высшего образования: опыт системного исследования. // Матер. межд. науч.теор. конф. Национальная система оценки качества образования: проблемы, стратегия, технология. Тараз: Тараз ун-ті, 2003. - С. 3254.

4. Греченко Д. А., Чулюков В. А. Структурная компонента модели организационного управления высшим учебным заведением // Современные наукоемкие технологии. 2010. - № 4. - С. 13-16.

5. Инноващии в управлении вузом: новые решения для корпоративной информационной системы / И. О. Красильников и [др.] // Университетское управление. - 2014. № 6 (46). - С. 16-24.

6. Каленюк I. С. Сучасні ризики розвитку вищої освіти в Україні / I. С. Каленюк, О. В. Куклін, В. А. Ямковий / / Економіка України. - 2015. № 2. - С. 70-83.

7. Домбровська С. М. Механізми реалізації державної політики в галузі вищої освіти / С. М. Домбровська // Актуальні проблеми держ. упр. - 2011. - № 2. - С. 107-113.

8. Красикова T. Ю. Образовательный кластер как фактор взаимодействия рынка труда и системы высшего профессионального образования / Т. Ю. Красикова // Актуальные вопросы экономики и управления: материалы междунар. науч. конф., апрель 2011 г.: тези доп. - М.: РИОР, 2011. - T. II. - C. 54-59.

9. Васильева Н. В. Формирование и развитие образовательных кластеров в региональной социально-економической системе: автореф. канд. экон. наук: спец. 08.00.05 “Экономи- 
ка и управление народным хазяйством (региональная экономика)” / Н. В. Васильева. - Гатчина, 2013. $26 \mathrm{c}$.

10. Корчагина Н. А. Образовательные кластеры как основа повышения конкурентоспособности учебных заведений / Н. А. Корчагина / / При- каспийский журн.: управление и высокие технологии. - 2009. - № 3 (7). - C. 78-84.

11. Смирнов A. B. Образовательные кластеры и инновационное обучение в вузе: монография / А. В. Смирнов. - Казань: РИЦ “Школа”, 2010. $102 \mathrm{c}$. 